\title{
Artificial marine habitats favour a single fish species on a long-term scale: the dominance of Boops boops around off-shore fish cages
}

\author{
Rodrigo Riera ${ }^{1}$, Pablo Sanchez-Jerez ${ }^{2}$, Myriam Rodriguez ${ }^{1}$, Oscar Monterroso ${ }^{1}$ \\ ${ }^{1}$ Centro de Investigaciones Medioambientales del Atlántico (CIMA SL), Arzobispo Elías Yanes, 44, 38206 La Laguna, \\ Tenerife, Canary Islands, Spain. E-mail: rodrigo@ cimacanarias.com \\ ${ }^{2}$ Departamento de Ciencias del Mar y Biología Aplicada, Universidad de Alicante, 99, 03080 Alicante, Spain.
}

\begin{abstract}
Summary: Off-shore fish cages are new artificial habitats that can affect pelagic fish assemblages and constitute an important food source for wild fish assemblages. This aggregation has noticeable ecological consequences in cage areas in impoverished ecosystems such as those in the Canary archipelago (NE Atlantic Ocean). However, this new habitat could be dominated by a single species, reducing its positive ecological effects. Wild fish assemblages associated with an off-shore fish lease on the northeastern coast of Tenerife (Canary Islands) were sampled for six years. Fish assemblage structure beneath fish cages and at controls ( $>500 \mathrm{~m}$ from cages) differed significantly between locations, with 13 times greater abundance at cage locations. These differences were mainly explained by the dominance of bogue (Boops boops) around fish cages. This trend was consistent in the long-term throughout the study period (2004-2009), affecting local fisheries. The presence of fish cages significantly altered wild fish assemblages in the study area, enhancing mainly biomass and abundance of one species, bogue, and causing shifts in species composition.
\end{abstract}

Keywords: off-shore; aquaculture; fisheries; fish; bogue; Canary Islands; Atlantic Ocean.

Los hábitats artificiales marinos favorecen a largo plazo a una única especie: la dominancia de Boops boops en las jaulas de acuicultura en mar abierto

Resumen: Las jaulas de acuicultura en mar abierto constituyen un hábitat artificial nuevo que puede afectar a las poblaciones de peces pelágicos porque constituyen una fuente importante de alimentación para las comunidades de peces salvajes. Esta congregación tiene consecuencias ecológicas notables en áreas caracterizadas por ecosistemas empobrecidos como ocurre en el archipiélago canario (Atlántico Noreste). Sin embargo, este nuevo hábitat puede encontrarse dominado por una única especie, limitando sus efectos ecológicos positivos. Las comunidades salvajes de peces asociadas a jaulas en mar abierto localizadas en la costa noreste de la isla de Tenerife (Islas Canarias) fueron muestreadas a lo largo de 6 años. La estructura de la comunidad íctica varió significativamente entre las localidades de las jaulas y los controles $(>500 \mathrm{~m}$ de distancia de las jaulas), con abundancias que fueron 13 veces superiores en las jaulas. Estas diferencias fueron debidas principalmente a la dominancia de la boga (Boops boops) alrededor de las jaulas de acuicultura. Esta tendencia fue consistente a lo largo del período de estudio (2004-2009), afectando a las capturas de los pescadores locales. La presencia de las jaulas de acuicultura afectó de forma significativa las poblaciones de peces en el área de estudio, con un incremento de la biomasa y abundancia de una especie, la boga, que determinó cambios en la composición de las especies.

Palabras clave: mar abierto; acuicultura; capturas; boga; Islas Canarias; océano Atlántico.

Citation/Como citar este artículo: Riera R., Sanchez-Jerez P., Rodriguez M., Monterroso O. 2014. Artificial marine habitats favour a single fish species on a long-term scale: the dominance of Boops boops around off-shore fish cages. Sci. Mar. 78(4): 505-510. doi: http://dx.doi.org/10.3989/scimar.04083.08A

Editor: E. Macpherson.

Received: April 24, 2014. Accepted: July 30, 2014. Published: October 15, 2014.

Copyright: () 2014 CSIC. This is an open-access article distributed under the Creative Commons Attribution-Non Commercial Lisence (by-nc) Spain 3.0.

\section{INTRODUCTION}

Dominance is of pivotal importance in conservation biology (Soul 1986). Ecological dominance is the degree to which a taxon is more numerous than its competitors in an ecological community, or makes up more of the total biomass (Dayton 1975). In the marine realm, dominant fish species may consume a high proportion of ecosystem resources, affecting the remaining species directly and indirectly. If a new habitat is 
especially suitable for one single species because of new trophic resources, individual fitness can help to increase population through optimal reproduction rates (Berryman 2003).

Artificial reefs and fish attraction devices (FADs) have traditionally been used to enhance populations of target species by favouring both spawners and recruits (Tupper and Boutilier 1997). It has been suggested that fish farms should be managed in a similar way as FADs (Sanchez-Jerez et al. 2011). Fish cages affect the presence, abundance, diet and residence times of wild fish assemblages, attracting a huge variety of species by providing food and refuge from predators (Valle et al. 2007, Boyra et al. 2004, Tuya et al. 2006). Large quantities of lost food pellets and faeces from cages are available to farm-aggregated wild fish (FernandezJover et al. 2008), actually altering biological conditions because of the high food availability (Skog et al. 2003, Fernandez-Jover et al. 2007).

The bogue (Boops boops) is gregarious, demersal to benthopelagic and mainly omnivorous (ArechavalaLopez et al. 2010), living on a variety of habitats (rocky substrates, sandy bare seabeds, seaweeds and seagrass meadows) from 0 to $350 \mathrm{~m}$ depth (Froese and Pauly 2007). It is an important prey for many piscivorous species (Kalogirou et al. 2012). In the Canary Islands the bogue has been traditionally fished to use as live bait for tuna (e.g. skipjack, Katsuwonus pelamis) (Ramos et al. 1995) and it has recently been used as a component of octopus diet in reared conditions (Estefanell et al. 2011). Therefore, this is of some ecological and economic importance for Canary coastal habitats.

In the Canary fish farms it has been previously observed that some species, including bogue, are short-term ( $<1$ year) dominant components (Boyra et al. 2004, Tuya et al. 2006). There is a recognition that it is important to deal with the prediction of human influence in key marine communities such as fish assemblages by testing ecological concepts through the observation of interannual temporal patterns.

In the present study we analysed the temporal trend of fish population aggregated to fish farms over six years (2004-2009), with the general aim of defining the temporal patterns of fish abundance during the study period, focussing especially on changes in community dominance. The main aims were (i) to define changes in fish assemblage composition by comparing fish cages and control areas; and (ii) to test whether bogue can be considered a dominant species and evaluate the importance of fish cages as a new pelagic habitat for bogue by comparing temporal trends from the establishment of aquaculture.

\section{MATERIALS AND METHODS}

\section{Study site}

The present study was conducted in an open fish cage located at Igueste de San Andrés (NE Tenerife, coordinates $\left.28^{\circ} 31^{\prime} 30^{\prime \prime} \mathrm{N} 16^{\circ} 09^{\prime} 20^{\prime \prime} \mathrm{W}\right)$. In the study area, two fish leases ( $c a .10000 \mathrm{~m}^{2}$ surface area) were situated $>300 \mathrm{~m}$ off the coast and both leases con-

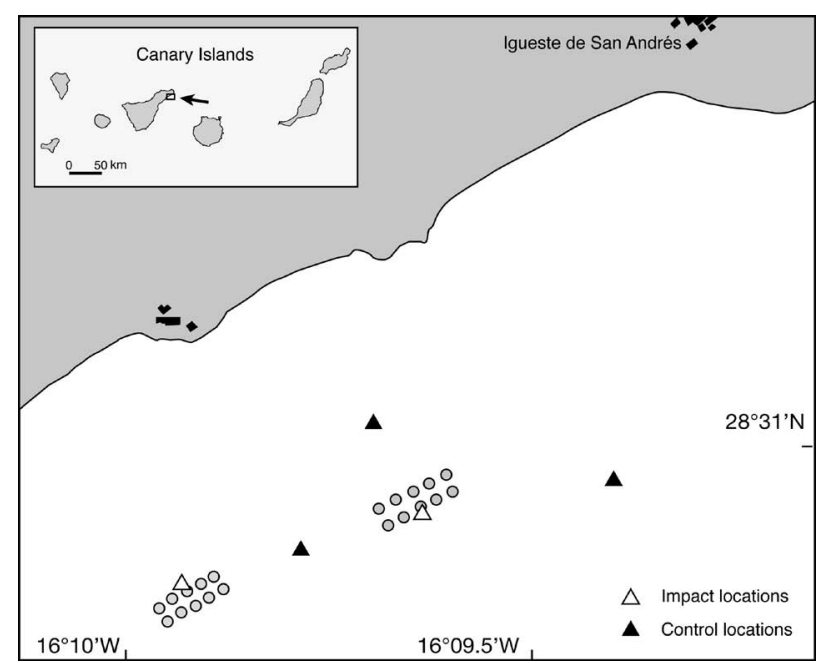

Fig. 1. - Map of the study area showing sampling locations.

sisted of ten 20-m-diameter cages (Fig. 1). Species cultured in the studied fish cages were gilt-head sea bream (Sparus aurata) (200 t) and sea bass (Dicentratus labrax) (150 t) from 2004 to 2007. From 2007 to $2009,450 \mathrm{t}$ were cultured in the studied fish leases (250 t of S. aurata $(250 \mathrm{t})$ and $200 \mathrm{t}$ of D. labrax). Fishes were fed both by hand and automatically using commercial, pelleted and extruded diets with an average nutrient content (on a dry weight basis) of $49 \%$ protein, $18.5 \%$ fat, $22 \%$ carbohydrate, $7.9 \%$ nitrogen and $1.08 \%$ phosphorus.

Each fish cage had a diameter of $20 \mathrm{~m}$ and reached a depth of $10 \mathrm{~m}$. Fish cages were installed on seabeds at a depth of 25-28 $\mathrm{m}$ and their temperature throughout the year ranged from $18^{\circ} \mathrm{C}$ in January to $22^{\circ} \mathrm{C}$ in September. Currents had a mean value of $7-8 \mathrm{~cm} \mathrm{~s}^{-1}$ in the water column (unpubl. data). There are no extensive seagrass meadows in the study area, only small patches of the seagrasses Cymodocea nodosa and Halophila decipiens. Rocky substrates are scarce in the subtidal but dominate in the intertidal of the study bay.

\section{Rapid visual count of fishes}

Total counts around cages were considered inappropriate as independent replicates due to obvious circling of cages by fishes. Instead, we conducted 5-min rapid visual counts (Kingsford and Battershill 1998) using SCUBA beginning at the centre of each sampling location and proceeding through the adjoining water mass. A total of six visual counts were conducted each time at each sampling location. Each count covered a volume of $c a .11250 \mathrm{~m}^{3}$ (15 m wide $\times 15 \mathrm{~m}$ deep $\times 50$ $\mathrm{m}$ long) at each location. Visibility was high, varying from 20 to $50 \mathrm{~m}$ on days when counts were performed and sea surface remained constant at all locations during the sampling campaign. Each count was made with two divers. The first diver concentrated on estimating the abundance of the dominant species, which were counted in groups of 1, 2-5, 6-10, 11-30, 31-50, 51$100,101-200,201-500$ and $>500$ to minimize error (Harmelin-Vivien et al. 1985). The second diver followed slightly behind the first and specifically looked 
for less obvious cryptic species and smaller individuals that may have been missed by the first diver. Counts of both divers were summed.

\section{Monitoring programme}

The monitoring programme was conducted over six years, from December 2004 to September 2009 during ten sampling campaigns (1 December 2004 [1 $\left.^{\text {st }}\right]$, April

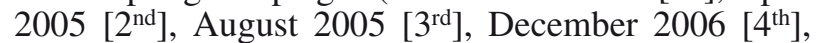

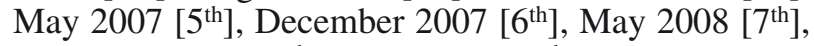
December 2008 [8 $\left.^{\text {th }}\right]$, April 2009 [9 $\left.^{\text {th }}\right]$ and September $2009\left[10^{\text {th }}\right]$ at each sampling location). Five locations were sampled throughout the study period (20042009), two located beneath the fish cages ("Impact", 25-28 m depth) and three over $500 \mathrm{~m}$ away that were not influenced by the cages ("control", 20-30 m depth) (Fig. 1). All sampling sites (impact and controls) were located on sandy bare seabeds with similar grain-size characteristics.

\section{Statistical analyses}

Non-parametric multivariate techniques were used to compare fish assemblages from impact and control locations, as well as, sampling times throughout the study period. All multivariate analyses were performed using the PRIMER statistical package (Clarke and Gorley 2006). Data were fourth-root transformed to weight the contributions of scarce species in the similarity coefficient (Clarke 1993). Similarity matrices were calculated using the Bray-Curtis similarity coefficient (Clarke and Warwick 1994). Non-metric MDS (n-MDS) was used as the ordination method to represent differences in fish composition between sampling groups (impact and control) throughout the study period. Taxa that had more influence on similarities of both location groups (impact and control) and dissimilarities between these groups of assemblages were calculated using the similarity percentages (SIMPER) procedure (Clarke 1993) to identify species responsible for the differences between groups (impact $v s$ control). Permutational multivariate analysis of variance (PERMANOVA) was applied to test for differences in fish assemblage structure, considering Year (2004-2009) and Impact (impact and control) as fixed factors.

Additionally, for analysing the temporal trend of bogue over the six-year period (2004-2009), bogue abundance was fitted by generalized additive models (GAM). This term includes any GLM estimated by quadratically penalized (possibly quasi-) likelihood maximization, using the MGCV package routines of R (www.r-project.org) (Wood 2011). The GAM regression technique consists of fitting smooth additive functions for each covariate included in the model structure. The smooth functions are linear combinations of a finite number of basis cubic spline functions, with the smoothness of the function estimated by minimizing the generalized cross-validation criterion (Wood 2011) that balances the goodness-of-fit and the smoothness of the functions. To avoid overfit- ting, we constrained the number of basic functions to at most three. We regressed each campaign variations of bogue abundances throughout the study period (2004-2009).

\section{RESULTS}

\section{Fish assemblage structure}

A total of 66672 fishes were observed during the study period (2004-2009) at the five sampling locations (impact and control). Bogue (Boops boops) was the dominant species (93.89\%), followed by black seabream (Spondyliosoma cantharus; $1.85 \%$ ) and white kingfish (Pseudocaranx dentex, 0.44\%). The remaining species (36 taxa) were very scarce $(<300$ individuals). Species richness was higher at impact $(13.2 \pm 1.06$ taxa, mean \pm SE) than at control locations (8.22 \pm 1.5 taxa) (Table 1$)$. The most common species in Impact locations were bogue (B. boops), black seabream (S. cantharus), white kingfish $(P$. dentex) and sharpnose puffer (Canthigaster capistratus). At control locations they were bogue (B. boops) and black seabream (S. cantharus). Differences between impact and control locations were more pronounced in terms of abundances since fishes were concentrated around fish cages $\left(6207.6 \pm 1816.4\right.$ ind $11250 \mathrm{~m}^{-3}$, mean $\left.\pm \mathrm{SE}\right)$, approximately 13 times more than at control locations $\left(456.9 \pm 257.8\right.$ ind $\left.11250 \mathrm{~m}^{-3}\right)$ (Table 1$)$. Bogue was present only at control locations of three campaigns throughout the study period, ranging in dominance (contribution to the overall fish abundance) from $50.84 \%$ in December 2007 to $96.52 \%$ in May 2008. In the impact group, bogue was present in all sampling campaigns, with the exception of May 2007. Bogue dominance varied from 69.65\% in December 2004 to $98.97 \%$ in April 2009 (Table 1). Shannon diversity showed the opposite pattern of fish abundances, with higher values at control $(1.13 \pm 0.2)$ than at impact locations $(0.54 \pm 0.13)$ (Table 1$)$ because of the

Table 1. - Overall species fish richness (S; number of species), fish abundance (A; number of individuals per $11250 \mathrm{~m}^{-3}$ ), Boops boops relative abundance $(\% \mathrm{Bb})$ and Shannon diversity $\left(\mathrm{H}^{\prime}\right)$ at control and impact locations throughout the study period (2004-09).

\begin{tabular}{llcccc}
\hline & Campaign & $\mathrm{S}$ & $\mathrm{A}$ & $\% \mathrm{Bb}$ & $\mathrm{H}^{\prime}$ \\
\hline Control & December-04 & 3 & 3 & 0 & 1.09 \\
& April-05 & 9 & 107 & 0 & 1.47 \\
& August-05 & 18 & 2556 & 67.68 & 0.97 \\
& December-06 & 7 & 56 & 0 & 1.59 \\
& May-07 & 5 & 9 & 0 & 1.52 \\
& December-07 & 11 & 1104 & 50.84 & 0.45 \\
& May-08 & 6 & 518 & 96.52 & 0.19 \\
& December-08 & 10 & 66 & 0 & 2.09 \\
& April-09 & 2 & 11 & 0 & 0.30 \\
& September-09 & 5 & 139 & 0 & 0.79 \\
Impact & December-04 & 8 & 201 & 69.65 & 1.09 \\
& April-05 & 16 & 1093 & 70.25 & 1.17 \\
& August-05 & 15 & 6246 & 88.05 & 0.57 \\
& Decemberr-06 & 13 & 3641 & 90.61 & 0.50 \\
& May-07 & 7 & 74 & 0 & 0.84 \\
& December-07 & 17 & 15596 & 98.64 & 0.98 \\
& May-08 & 14 & 9633 & 97.88 & 0.16 \\
& December-08 & 16 & 8690 & 97.05 & 0.19 \\
& April-09 & 12 & 14549 & 98.97 & 0.73 \\
& September-09 & 14 & 2353 & 87.53 & 0.70 \\
\hline
\end{tabular}


Table 2. - Results of PERMANOVA testing for differences in fish assemblage structure during study years ("Year" fixed factor) and between locations ("Impact", fixed factor). Significant differences $(\mathrm{p}<0.01)$ are highlighted in bold. Results of pairwise comparisons between locations for each year are included as a result of a significant interaction between Year and Impact.

\begin{tabular}{lrrrrrr}
\hline \multicolumn{1}{c}{ Source } & df & \multicolumn{1}{c}{ SS } & MS & Pseudo-F & p \\
\hline Year & 5 & 66594 & 13319 & 96.246 & $\mathbf{0 . 0 0 1}$ & $2004<2005,2006<2007-2009$ \\
Impact & 1 & 53967 & 53967 & 38.999 & $\mathbf{0 . 0 0 1}$ & \\
Year $\times$ Impact & 5 & 23375 & 4675 & 33.783 & $\mathbf{0 . 0 0 1}$ & \\
Res & 234 & $3.24 \mathrm{E}+05$ & 1383.8 & & \\
Total & 245 & $4.88 \mathrm{E}+09$ & & & \\
\hline
\end{tabular}

dominance of few species. Shannon diversity in the control group ranged from $0.30 \pm 0.11$ in April 2009 to $2.09 \pm 1.18$ in December 2008, whereas in the impact group it ranged from $0.16 \pm 0.09$ in May 2008 to $1.17 \pm 0.67$ in April 2005 (Table 1).

SIMPER analysis showed higher similarity at impact locations $(32.57 \%)$ than at control locations (7.64\%). A total of seven fish species were the most important contributors to the impact group similarity (Boops boops, Canthigaster capistrata, Bothus podas, Trachinus draco, Sphoeroides marmoratus, Dasyatis pastinaca and Taeniura grabata), though most of the contribution to the assemblage homogeneity was provided by the bogue (55.43\%). This species overwhelmingly dominated the overall fish abundance and thus changed the whole assemblage structure. The similarity in the control group was mainly due to Trachinus draco, which was responsible for $27.60 \%$ of homogeneity, followed by Sphoeroides marmoratus (20.75\%).

Bogue was the most important species for explaining the dissimilarity between the two groups $(91.43 \%$ dissimilarity), with a contribution of $30.89 \%$. The remaining fish were scarcely responsible for the dissimilarity, with low percentages per species $(<10 \%)$. Bogue dominated fish assemblages at control locations ( $70 \%$ of abundance), but the percentage of dominance was lower than at impact sites (96\% of abundance) and other species (e.g. black seabream (Spondyliosoma cantharus)) contributed significantly to the overall fish structure (Table 1).

\section{Temporal changes in fish abundance}

Similarity in caged stations within each year ranged from $5.25 \%$ (2004) to $69.68 \%$ (2006). Bogue contributed consistently throughout the study period at caged

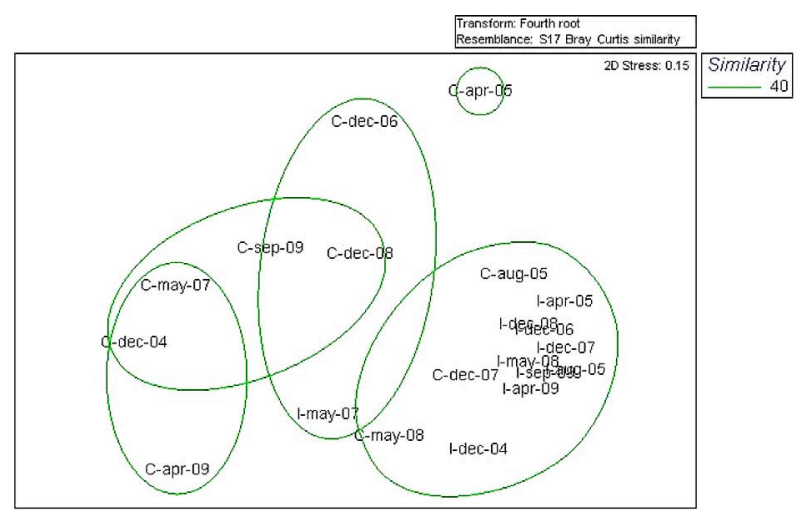

Fig. 2. - n-MDS of sampling campaigns considering months and years. I, impact locations; C, control locations. Circles indicate $40 \%$ similarity.

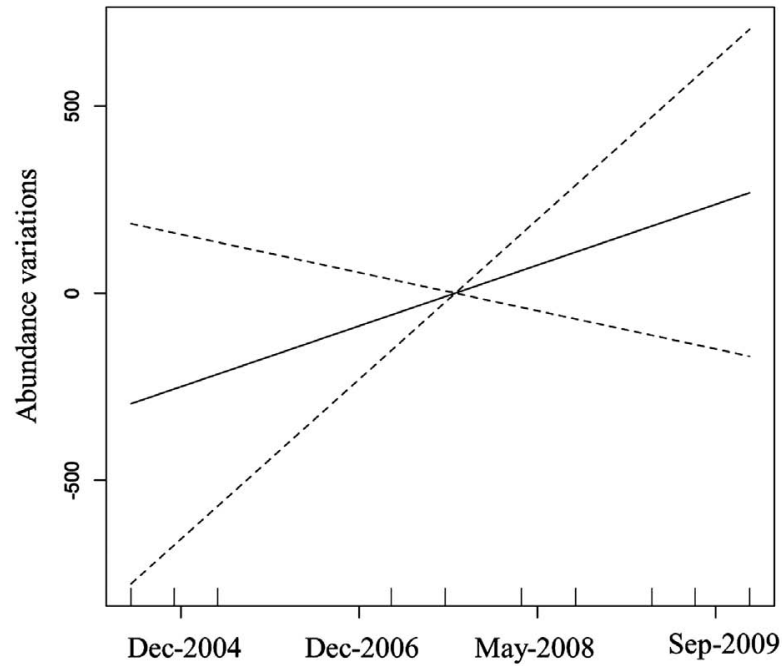

Fig. 3. Temporal trend of Boops boops population modelled by GAM during the study period (2004-2009).

stations from $48.58 \%$ (2007) to $97.85 \%$ (2008), with a mean contribution of $78.25 \%$. The abundance variations of bogue were the main factors responsible for dissimilarities at caged stations among years, varying from $53.31 \%$ (2005-2006) to $96.89 \%$ (2004-2007).

Highly significant differences were obtained in the YearxImpact interaction (Table 2). Fish assemblage structure was significantly different between locations beneath fish cages and controls (Impact Pseudo$\mathrm{F}=96.246, \mathrm{p}=0.001$ ), but these differences showed interannual variations (Year $\times$ Impact, Pseudo $F=33.783$, $\mathrm{p}=0.001$ ) (Table 2, Fig. 2). Temporal variability was more pronounced at control locations (5 different groups) due to low fish abundances and aggregated distribution. Impact locations were included in one group, except in May 2007 (Fig. 2).

The analysis of the temporal trend of the bogue population by GAM showed an increasing pattern over the study period (Fig. 3), especially due to the high abundances of bogue in the last sampling years (2007-2009).

\section{DISCUSSION}

Wild fish aggregation around cages has been described worldwide (Sanchez-Jerez et al. 2011), with assemblages dominated by a limited number of fish species, e.g. Boops boops in the Mediterranean Sea and Canary Islands (NE Atlantic Ocean) and Pollachius virens in Norwegian fjords. The remaining aggregated species are accessory and scarce (Boyra et al. 2004, 
Dempster et al. 2009). However, these structures can be used as a habitat for fishes until they become adults, and recruitment of juveniles is one of the most important interactions between wild fish and cages (Valle et al. 2007).

In the present study, the largest concentrations of wild fish occurred beneath off-shore cages, with an effect size of a 13 times greater abundance at farms compared with controls at a distance of $500 \mathrm{~m}$, mainly due to one single species: bogue (Boops boops). The bogue dominated the fish assemblage beneath farms throughout the study period and interannual variations (2004-2009) were observed, with maximum densities in the period 2007-2009, which may be interpreted as a long-term population increase due to the increase of aquaculture production rates in studied fish leases, from $300 \mathrm{t}$ (2004-06) to $450 \mathrm{t}$ (from 2007 to 2009). Boops boops dominated throughout the year, being slightly more abundant in spring and summer months (March-September).

In the Mediterranean Sea, bogues are a significant component of wild fish assemblages around off-shore cages (Fernandez-Jover et al. 2008), especially during winter months (January-April) (Valle et al. 2007). Seasonal changes in fish assemblages are less pronounced at subtropical latitudes (e.g. the Canary Islands) (Boyra et al. 2004), possibly due to more stable environmental conditions such as low temperature variations during the year $\left(18-22^{\circ} \mathrm{C}\right)$. Our results showed inconsistent seasonal trends, but a progressive increase in bogue abundances was observed throughout the study period, with special emphasis during the last three years (2007-09).

Fish farms concentrate large numbers of predatory species of commercial interest, such as Coryphaena hippurus, Seriola dumerilii, Pomatomus saltratix, Dentex dentex and Thunnus thynnus (Dempster et al. 2002, 2005, 2010, Valle et al. 2007), which are attracted by fish aggregations. This attraction has consequences of the utmost importance for local artisanal fisheries (Machias et al. 2006, Fernandez-Jover et al. 2007, 2009, Luna-Perez et al. 2010), and leads to high fishing pressure from commercial and recreational vessels around farms in the western Mediterranean (Arechavala-Lopez et al. 2010, Luna-Perez et al. 2010).

In the Canary Islands, fishes particularly attracted to farms and of commercial interest are Sphyraena viridensis, Pagellus acarne and carangids (Trachinotus ovatus, Pseudocaranx dentex and Seriola spp.) (Boyra et al. 2004). This attraction is particularly enhanced in areas with a decline of the coastal resources, such as the Canary archipelago, with an overexploitation and severe depletion of fish assemblages (Falcon et al. 1996, Tuya et al. 2005). Even artisanal fisheries shifts are related to these aggregations in the Canary archipelago. For example, the bogue was considered a fishery resource of secondary importance or even used as bait for several tuna species and for experimental octopus culture (Estefanell et al. 2011). However, the bogue is currently considered one of the main catches by artisanal fisheries in the study area (NE Tenerife), with catches of around $800 \mathrm{~kg} /$ year (data from fisherman's association in the study area).
The opportunistic behaviour of the bogue provides ecological advantages throughout its life cycle compared with other fish, as has been demonstrated in the present long-term data series (2004-2009). The bogue takes advantage, whenever accessible, of food resources from off-shore fish cages and alternates these periods with natural diet obtained in the surrounded area, as previously observed in the Mediterranean Sea (Arechavala-Lopez et al. 2010).

In short, coastal fish farms attract wild fish, but only a few species such as the bogue are well-adapted to cages and dominated fish assemblages around Canary Island off-shore farms. This adaptive behaviour seems to favour a population increase in the long term (six years) and could have implications for natural predators and local fisheries. Therefore, off-shore fish cages should be taken into account in fisheries management as they may strongly affect fish populations and may have an indirect effect on fish assemblages and the entire coastal ecosystem.

\section{ACKNOWLEDGEMENTS}

The remaining staff of the Centro de Investigaciones Medioambientales del Atlántico (CIMA SL) are thanked for providing logistic support during field campaigns throughout the study period. CEDRA SLL and SUDOESTE SL are thanked for providing financial support. Last but not least, José Pérez (CEDRA SLL) is thanked for providing production data and for his encouragement during the environmental monitoring studies of the fish cages. The collaboration of PSJ was funded by the Spanish Ministry of Science through the FATFISH project (CTM2009-14362-C02-01).

\section{REFERENCES}

Arechavala-Lopez P., Sanchez-Jerez P. Bayle-Sempere J, et al. 2010. Direct interaction between wild fish aggregations at fish farms and fisheries activity at fishing grounds: a case study with Boops boops. Aquac. Res. 1: 1-15.

Berryman A.A. 2003. On principles, laws and theory in population ecology. Oikos 103: 695-701. http://dx.doi.org/10.1034/j.1600-0706.2003.12810.x

Boyra A., Sanchez-Jerez P., Tuya F., et al. 2004. Attraction of wild coastal fishes to an Atlantic subtropical cage fish farms, Gran Canaria, Canary Islands. Env. Biol. Fish. 70: 393-401. http://dx.doi.org/10.1023/B:EBFI.0000035435.51530.c8

Clarke K.R. 1993. Non-parametric multivariate analyses of changes in community structure. Aust. J. Ecol. 18: 117-143. http://dx.doi.org/10.1111/j.1442-9993.1993.tb00438.x

Clarke K.R., Gorley R.N. 2006. PRIMER v6: User Manual/Tutorial. PRIMER-E, Plymouth, UK.

Clarke K.R., Warwick R.M. 1994. Changes in Marine Communities. Plymouth Marine Laboratory, 144 pp.

Dayton P.K. 1975. Experimental evaluation of ecological dominance in a rocky intertidal algal community. Ecol. Monog. 45: $137-159$. http://dx.doi.org/10.2307/1942404

Dempster T., Sanchez-Jerez P., Bayle-Sempere J.T., et al. 2002. Attraction of wild fish to sea-cage fish farms in the south-western Mediterranean Sea: spatial and short-term temporal variability. Mar. Ecol. Prog. Ser. 242: 237-252. http://dx.doi.org/10.3354/meps242237

Dempster T., Fernandez-Jover D., Sanchez-Jerez P., et al. 2005. Vertical variability of wild fish assemblages around sea-cage fish farms: implications for management. Mar. Ecol. Prog. Ser. 304: 15-29.

http://dx.doi.org/10.3354/meps304015 
Dempster T., Uglem K., Sanchez-Jerez P., et al. 2009. Coastal salmon farms attract large and persistent aggregations of wild fish: an ecosystem effect. Mar. Ecol. Prog. Ser. 385: 1-14. http://dx.doi.org/10.3354/meps08050

Dempster T., Sanchez-Jerez P., Uglem I., et al. 2010. Speciesspecific patterns of aggregation of wild fish around fish farms. Est. Coast. Shelf Sci. 86: 271-275. http://dx.doi.org/10.1016/j.ecss.2009.11.007

Estefanell J., Roo J., Guirao R., et al. 2011. Efficient utilization of dietary lipids in Octopus vulgaris (Cuvier 1797) fed fresh and agglutinated moist diets based on aquaculture by-products and low price trash species. Aquac. Res. 35: 1-13.

Falcon J.M., Bortone S.A., Brito A., et al. 1996. Structure and relationships within and between the littoral rock-substrate fish communities off four islands in the Canarian archipelago. Mar. Biol. 125: 215-231. http://dx.doi.org/10.1007/BF00346302

Fernandez-Jover D., Lopez-Jimenez J.A., Sanchez-Jerez P., et al. 2007. Changes in body condition and fatty acid composition of wild Mediterranean horse mackerel (Trachurus mediterraneus Steindachner, 1868) associated with sea cage fish farms. Mar. Env. Res. 63: 1-18. http://dx.doi.org/10.1016/j.marenvres.2006.05.002

Fernandez-Jover D., Sanchez-Jerez P., Bayle-Sempere J.T., et al. 2008. Seasonal patterns and diets of wild fish assemblages associated to mediterranean coastal fish farms. ICES J. Mar. Sci. 65: $1153-1160$ http://dx.doi.org/10.1093/icesjms/fsn091

Fernandez-Jover D., Sanchez-Jerez P., Bayle-Sempere J.T., et al. 2009. Coastal fish farms are settlement sites for juvenile fish. Mar. Env. Res. 68: 89-96. http://dx.doi.org/10.1016/j.marenvres.2009.04.006

Froese R., Pauly D. 2007. Fishbase. Available at http://www.fishbase.org (accessed May 2012)

Harmelin-Vivien M.L., Harmelin-Vivien J.G., Chauvet C., et al. 1985. Evaluation visuelle des peuplements et populations de poissons: Méthodes et problèmes. Terre \& Vie, 40: 467-539.

Kalogirou S., Mittermayer F., Pihl L., et al. 2012. Feeding ecology of indigenous and non-indigenous fish species within the family Sphyraenidae. J. Fish. Biol. 80(7): 2528-2548. http://dx.doi.org/10.1111/j.1095-8649.2012.03306.x

Kingsford M., Battershill C. 1998. Studying marine temperate environments: a handbook for ecologists, Canterbury University Press, Christchurch, New Zealand, 335 pp.

Luna-Pérez B., Forcada A., Bayle-Sempere J.T., et al. 2010. Assessing recreational fihing impact at Serra Gelada Marine Park
(SW Mediterranean): a baseline study for its future regulation. XVI Simposio Ibérico de Estudio de Biología Marina (Alicante, Spain). 6-10th September 2010

Machias A., Giannoulaki M., Somarkis S., et al. 2006. Fish farming effects on local fisheries landings in oligotrophic seas. Aquaculture, 261: 809-816. http://dx.doi.org/10.1016/j. aquaculture.2006.07.019

Ramos A.G., Lorenzo J.M., Pajuelo J.G., 1995, Food habits of bait-caught skipjack tuna Katsuwonus pelamus off the Canary Islands. Sci. Mar. 59: 365-369.

Sanchez-Jerez P., Dempster T., Fernandez-Jover D., et al. 2011. Coastal fish farms act as fish aggregation devices (FADs): potential effects on fisheries. In: Bortrone S. (ed) Artificial reefs in fisheries management. CRC Press, Boca Raton, Florida, USA: 187-208. http://dx.doi.org/10.1201/b10910-13

Skog T.E., Hylland K., Torstensen B.E., et al. 2003. Salmon farming affects the fatty acid composition and taste of wild saithe Pollachius virens L. Aquac. Res. 34: 999-1007. http://dx.doi.org/10.1046/j.1365-2109.2003.00901.x

Soul E. 1986. Conservation Biology: The Science of Scarcity and Diversity. Sinauer Associates, Sunderland, Massachussets, 584 pp.

Tupper, M., Boutilier, R.G. 1997. Effects of habitat on settlement, growth, predation risk and survival of a temperate reef fish. Mar. Ecol. Prog. Ser. 151: 225-236. http://dx.doi.org/10.3354/meps151225

Tuya F., Sanchez-Jerez P., Boyra A., et al. 2005. Non-metric multivariate analysis of the demersal icthhyofauna along soft bottoms of the Eastern Atlantic: comparison between unvegetated substrates, seagrass meadows and sandy bottoms under the influence of sea-cage fish farms. Mar. Biol. 147: 1229-1237. http://dx.doi.org/10.1007/s00227-005-0018-1

Tuya F., Sanchez-Jerez P., Dempster T., et al. 2006. Changes in demersal wild fish aggregations beneath a sea-cage fish farm after the cessation of farm. J. Fish Biol. 69: 682-697. http://dx.doi.org/10.1111/j.1095-8649.2006.01139.x

Valle C., Bayle-Sempere J.T., Dempster T., et al. 2007. Temporal variability of wild fish assemblages associated with a sea-cage fish farm in the southwestern Mediterranean Sea. Est. Coast. Shelf Sci. 72: 299-307. http://dx.doi.org/10.1016/j.ecss.2006.10.019

Wood S.N. 2011. Fast stable restricted maximum likelihood and marginal likelihood estimation of semiparametric generalized linear models. J. Roy. Stat. Soc. 3: 3-36. http://dx.doi.org/10.1111/j.1467-9868.2010.00749.x 